\title{
LEARNER AUTONOMY IN THE INDONESIAN EFL SETTINGS
}

\author{
Nenden Sri Lengkanawati \\ Universitas Pendidikan Indonesia \\ nendensl@indo.net.id
}

First received: 10 August 2016

Final proof received: 15 January 2017

\begin{abstract}
Learner autonomy in Indonesian educational institutions has not commonly been listed as a teachinglearning objective, and most teachers seem to be hardly acquainted with learner autonomy (LA). Therefore, it is very essential to conduct a study of LA as perceived and experienced by school teachers and to find out the importance of LA training for professional development. A questionnaire was used to collect the data about English teachers' perceptions regarding LA and LA-based practices. In addition, an LA training was conducted to see its significance for professional development. After the data were quantitatively and qualitatively analyzed, it was found that the participating teachers tended to maintain that autonomy should be inculcated among learners, and that the LA concept should not be misinterpreted as learning without a teacher. Concerning choices and decisions by the learners, it was believed that learners' making choices about how they learned and what activities they did, and involving them to decide what and how to learn could promote autonomy among learners. As regards LA-based teaching-learning practices, it was revealed that most teachers desired to implement LA principles in their teaching-learning contexts, although they identified that many of the LA principles were not that feasible to apply in their situation. It was also found that LA training could improve the teachers' perceptions regarding LA concepts and principles. There were some constraints which could make learner autonomy difficult to develop among Indonesian learners in general: limited time allotted for the implementation of the curriculum, learners' lack of autonomous learning experience, too much focus on national examinations, and insufficient proficiency of English. LA-based teaching-learning practices were most desired; however, many were considered as having insufficient feasibility. In this respect, commitment is certainly the key to success in inculcating LA principles as well as implementing them in the classroom setting.
\end{abstract}

Keywords: learner autonomy; autonomous learners; professional development; national examination

The term autonomous learning refers to the ability of the learner to take charge of one's own learning by making himself capable of making his own decision in determining learning objectives, defining the contents and his progress, selecting methods and techniques, monitoring the procedures of acquisition, and evaluating what has been acquired. Holec(1981) cited by Cotterall (2008) also sees autonomy as a potential capacity which needs to be developed in learners. However, Lengkanawati (2014a) reported that LA was very rarely discussed in Indonesian literature. Lamb (2004) mentions that autonomous language learning refers to Western and tertiary education level. He also perceives that LA in language learning is more problematic in Asian secondary level contexts. In a similar vein, Harmer (2007) affirms that in British, Australian, and American culture, people consider LA as the most central and important parts of the teaching and learning outcome. In the Indonesian context, Lengkanawati (1997) states that LA is less commonly utilized compared to that in the Western context. In line with this issue, Borg and Busaidi (2012) say that even though LA has been a key theme in the field of foreign language learning for over 30 years, the space for availability of extensive literature is limited.

Language teachers in Indonesia have to face the reality that reading ability of our students ranks very low at the international standard, 61st out of 64 countries, as assessed by the OECD Program for International Student Assessment. In terms of students' quality, as it was reported by the 2011 Trends in International Mathematics and Science Study (TIMSS), Indonesian students' higher order thinking ability is considered as low (Mullis, Martin, Foy, \& Arora, 2012). These problems might have something to do with the incompetency of the teachers. Baswedan (2014) reported that based on the certification exam administered to 460 teachers in Indonesia in 2012, on average, the average teacher score was only 44.5, far lower than which was expected to reach, that is 70 .

Nuh (2013) reported that English as a Foreign Language (EFL) proficiency of our high school graduates is not promising as overall they were still at the elementary level, despite the goal of an intermediate level for senior high school graduates. The implementation of 2013 curriculum gives new 
expectations in the learning process since the curriculum expects that there should be a change in the teaching and learning process, from transferring knowledge or giving information by the teacher to the students to allowing students to find information by themselves. In this matter, we could say that students should be trained to become autonomous by using learning strategies which in turn will make them capable of improving their learning by themselves. Bialystok and Frohlich, cited by Cohen and Macaro (2013), found that the combined use of three learning strategies-practising, inferencing, and monitoring could make students responsible for their achievement in reading, listening and grammar tests.

Lengkanawati (2014b) believes that if we teach learners learn how to learn by the use of learning strategies, it is inevitable that we make them become autonomous which in turn will help them have better learning outcomes. She suggests that teachers should promote LA. It is in line withDornyei (2011) who was convinced by some research results and also with some evidence that learners who are capable of learning independently may gain greater proficiency. He further says that autonomy in educational psychology is a self-regulation in learning

Considering the problems mentioned earlier and the great impact of LA on students' proficiency, LA is actually crucial to be implemented in the Indonesian settings. Research in this area would contribute as well to fostering better implementation of the 2013 curriculum which is believed to nurture LA. Therefore, the present study sought to shed light on the potential practices of LA in the Indonesian EFL settings as perceived by the teachers and based on their experience as well how significant LA training for professional development is. It is expected that the findings of this study will put forward salient points for the development and promotion of LA in Indonesian contexts, which in turn will be beneficial for the improvement of effective teaching and learning process to promote better learning outcomes.

Lengkanawati (2014a) states that in the Indonesian contexts autonomous learning refers to a situation where students use language learning strategies to make themselves become autonomous learners. This definition is in line with Wenden (1991, p.15) who affirms that autonomous learners are learners who "...learn how to learn to acquire the learning strategies, the knowledge about learning, and the attitudes to use these skills and knowledge confidently, flexibly, appropriately, and independently of a teacher." Dickinson as quoted by Oxford (1990) says that learner autonomy refers to the learning mode, situation, or techniques associated with the responsible attitude. Oxford (1990) addsthe term self-direction, which refers to learning mode, situation, or techniques and the term autonomy refers to the learner's attitude. Following studies by Benson (2007) and Oxford (2003), LA has been looked at by Borg and Al-Busaidi (2012) as having four distinct perspectives: technical, psychological, political, and sociocultural.

All the definitions above seem to have significant roles in the process of learning to support students' learning outcome. The concept of autonomy, which is frequently associated with the concepts of independent learning, self-directed and self-regulated learning has been viewed as fundamental components of good teaching and learning (Benson \& Huang, 2008).Kumaravadivelu (2003, p.39) promotes macro-strategies in learning. One of the macro-strategies he promotes is fostering learner autonomy. He further says that this macro-strategy involves helping learners learn how to learn, equipping them with the means necessary to self-direct and self-monitor their own learning. $\mathrm{He}$ also affirms that helping learners become autonomous is one way of maximizing their chances for success.

However, in the Indonesian context, LA is still considered as an almost unfamiliar concept to both teachers and learners in the teaching and learning process.From experience, we can see that no matter how experienced a teacher is, if no efforts are done by the students through working on their learning individually outside the class and by being active participants in the teaching and learning process, the successful learning outcome would not take place. In other words, promoting LA through training is likely very important to pursue better learning outcome. Harmer (2007) believes that students will take the responsibility for their own learning if they are trained about how they learn and how the learning can be made more effective. To promote autonomy, Harmer (2007) says, teachers cannot just tell their students about the significant roles of becoming autonomous in learning. It is suggested that LA should be included in the course design, which is also important to help students find ways to become independent in learning.

Benson et al. (2003) in his study found the importance of sustaining the learning activity of the two successful Asians in their study. Lamb (2004), in his study with the 11-12-year-old Indonesians, found that there is a clear picture of which sustained autonomous learning behavior emerges. Their learning many times takes place outside of formal English classes at home or at private courses. Lamb (2004) reported Benson et al.'s study (2003) which found that the independent learning of English is as a communication tool rather than as a school subject. This is an assertion of the individual autonomy.

English is compulsory for Indonesian students from junior high school levels up to the tertiary levels. A senior high school graduate is expected to reach the intermediate level of his/her English proficiency. However, as reported by Hamied (2011) the majority of senior high school students (almost 
95\%) were grouped into the novice and elementary levels as assessed by the TOEIC conducted by ITC, Jakarta. Based on the report of PISA, almost all Indonesian students could accomplish only up to level 3 at Mathematics, language, and science, whereas in some other countries they could reach up to level 4, 5, or even 6 . The PISA results for Indonesian students are the second lowest in the league table, worse than the last PISA in 2009, when Indonesia ranked 57th. The result shows the Indonesian education system is going nowhere, despite massive investment.

The problem mentioned above has triggered the Ministry of Education and Culture in Indonesia to launch the new Curriculum-the 2013 Curriculum (Ministry of Education, 2012). In the most recent national curriculum (Ministry of Education, 2012), the teaching and learning process is expected to support students in learning how to learn by finding information by themselves. The scientific approach and problem solving activities are to be utilized in the teaching and learning process. This implies that autonomous learning is now considered to be fundamental in the teaching and learning process.

In line with these research results, Utami (2007) looked at the efforts of autonomous learners to improve their English. Using a case study design involving eight students at a college in Bandung, she found that autonomous learners involved in her study possessed some characteristics of autonomous learners such as taking responsibility of their own learning, being aware of needs, setting goals, planning their own learning, finding resources, allocating time, and working collaboratively. She added that in the process of learning, the students were influenced by psychological and socio-cultural factors.

Lengkanawati (2014a), in her study, reported that LA and Language Learning Strategies (LLS) correlated significantly with students' proficiency. The results show that the students' proficiency were reflected in both LLS and LA. However, the inferential ANOVA results showed the students' autonomy was significantly differentiated only by the students' proficiency levels. It could therefore be concluded that students' proficiency could be reflected in their LLS use and more obviously in their autonomy. It is recommended that LLS and autonomy trainings would be valuable to assist students in learning how to learn. In line with this study, Miyartawan (2013) reported that LA and English proficiency had a strong, positive, and significant correlation.

Nunan (2000, p.1, cited by Suharmanto, 2003) has indicated that weaknesses in educational settings could possibly be improved by means of learning autonomy, "a learning situation which implies a capacity to exercise control over one's own learning". Suharmanto (2003) also reported the studies reported bySadtono(1976) and Diptoadi et al. (2002) which indicate that successful Indonesian EFL learners were to some degrees related to their being autonomous learners. They take control of their learning and use their own learning strategies to solve their learning problem in order to meet their own learning objectives.

In line with these research results, Utami (2007) looked at the efforts of autonomous learners to improve their English. Using a case study design involving eight students at a college in Bandung, she found that autonomous learners involved in her study possess some characteristics of autonomous learners such as taking responsibility of their learning, being aware of needs, setting goals, planning their own learning, finding resources, allocating time, and working collaboratively. She added that in the process of learning, the students were influenced by psychological and sociocultural factors.

Based on her study, Kemala (2014) affirms that autonomous learners arecharacterised by the ability of finding resources or materials they intended to learn, identifying their learning needs and selecting the learning projects. In regards to learning strategies, she explained that the autonomous learners use memory strategies, social strategies, cognitive strategies, and meta-cognitive strategies. She reported that in the interview, it could be concluded that motivation, environment, task, teacher, and material played important roles to make students autonomous in learning.

\section{METHOD}

A descriptive analytical approach was adopted as its design with a qualitative analysis for data interpretation. The study sought to shed light on teachers' perceptions regarding learner autonomy principles and the common LA-based practices in the teaching learning process. The study also tried to take a look at the teachers' perception of the significance of LA training for professional development. The subjects of the study were Indonesian English teachers who were studying at a master's degree program in the university. They were voluntarily recruited in the study, on the basis of their enthusiasm to take part. To address the research questions, data were collected from the questionnaire and through observations during the professional development workshops. The research questions were formulated as follows: (1) What are the teachers' perceptions regarding learner autonomy principles?, (2) What are common LAbased teaching learning practices as reported by the teachers?, and (3) How significant is LA training for professional development?

The questionnaire developed and modified on the basis of Borg and Busaidi's (2012) was e-mailed to 60 potential subjects and 58 of them filled out and 
returned the questionnaires, of which 48 filled out questionnaires were analyzed as the rest were no longer active in the teaching profession. An LAtraining was carried out involving those respondents and after the training, the same questionnaire was administered again to the participants to see whether their perceptions regarding LA improved.

Data from the questionnaire was analysed statistically using Statistical Package for Social Sciences (SPSS). All questions covered in the questionnaire were calculated using descriptive statistics to take a look at frequency counts and percentages. To examine the participants' perception on the significance of LA training, inferential statistics were also used. Utilising the mixed methods in nature of this study, data analysis also involved data transcription and interpretation.

\section{FINDINGS AND DISCUSSION \\ Perceptions on LA principle}

In this study, perceptions of English teachers were gained by administering a quuestionnaire covering four perspectives: technical, political, psychological and social as has been indicated by Borg and AlBusaidi (2012). Items on facilities of learning such as internet, self-access center, and use of the library were grouped intothe technical perspectives, whereas such learning-related factors as age, motivation, confidence, learning effectiveness, and learner-centeredness are categorized into the psychological perspectives. Factors such as opportunities, choices, decisions, freedom and teacher-centeredness belong to the political perspectives, and, factors such as backgrounds, collaboration, and western/non-western-related issues were grouped into thesociocultural perspectives.

Interesting findings were revealed in this study as regards the subjects' perceptions on LA principles. It was found that, concerning the technical perspectives, the majority (above 60\%) agreed, some even strongly agreed, that learner autonomy could be developed through such activities as independent study in the library, learning outside the classroom, independent work in a self-access center, and out of class tasks involving use of the internet. This last activity was identified by $91.7 \%$ of the subjects as having the potential to develop learner autonomy. But, when asked whether learner autonomy meant learning without a teacher, the majority disagreed orstrongly disagreed. This means that teachers' role is still perceived by a big portion of the teachers as it is needed to createa more effective teaching-learning process. It was also found that total independence of the teacher was perceived not to be required for learner autonomy to take place as the majority of the teachers disagreed and strongly disagreed to the concept of total independence.The data, as can be seen in Table 1, indicate that themajority of the teacherswere against the idea that LA means learning without a teacher.

Table 1.Teachers' perceptionss on LA: Technical perspectives

\begin{tabular}{|c|c|c|c|c|c|c|c|}
\hline No & Statement & 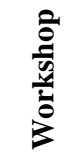 & 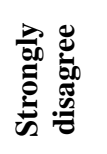 & 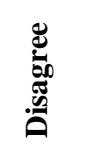 & 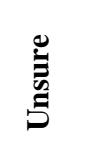 & 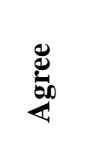 & 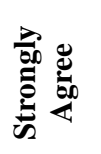 \\
\hline & \multirow{2}{*}{$\begin{array}{l}\text { Independent study in the library is an } \\
\text { activity which developsLA. }\end{array}$} & Pre- & $2.1 \%$ & $4.2 \%$ & $18.8 \%$ & $60.4 \%$ & $14.6 \%$ \\
\hline & & Post- & $0.0 \%$ & $3.3 \%$ & $0.0 \%$ & $40.0 \%$ & $56.7 \%$ \\
\hline \multirow[t]{2}{*}{2.} & \multirow{2}{*}{$\begin{array}{l}\text { Autonomy can develop most effectively } \\
\text { through learning outsidethe classroom. }\end{array}$} & Pre- & $4.2 \%$ & $14.6 \%$ & $14.6 \%$ & $58.3 \%$ & $8.3 \%$ \\
\hline & & Post- & $0.0 \%$ & $30.0 \%$ & $16.7 \%$ & $0.0 \%$ & $53.3 \%$ \\
\hline \multirow[t]{2}{*}{3.} & \multirow[t]{2}{*}{ LA means learning without a teacher. } & Pre- & $12.5 \%$ & $45.8 \%$ & $25.0 \%$ & $12.5 \%$ & $4.2 \%$ \\
\hline & & Post- & $13.3 \%$ & $66.7 \%$ & $16.7 \%$ & $0.0 \%$ & $3.3 \%$ \\
\hline & \multirow{2}{*}{$\begin{array}{l}\text { LA is promoted by independent work in a } \\
\text { self-access centre. }\end{array}$} & Pre- & $8.3 \%$ & $12.5 \%$ & $16.7 \%$ & $52.1 \%$ & $10.4 \%$ \\
\hline & & Post- & $0.0 \%$ & $10.0 \%$ & $10.0 \%$ & $20.0 \%$ & $60.0 \%$ \\
\hline \multirow[t]{2}{*}{5 . } & \multirow{2}{*}{$\begin{array}{l}\text { LA requires the learner to be totally } \\
\text { independent of the teacher. }\end{array}$} & Pre- & $8.3 \%$ & $\mathbf{5 0 . 0 \%}$ & $27.1 \%$ & $14.6 \%$ & $0.0 \%$ \\
\hline & & Post- & $6.7 \%$ & $66.7 \%$ & $10.0 \%$ & $0.0 \%$ & $16.7 \%$ \\
\hline \multirow[t]{2}{*}{6.} & \multirow{2}{*}{$\begin{array}{l}\text { Out-of-class tasks which requires learners to } \\
\text { use the internet promote LA. }\end{array}$} & Pre- & $2.1 \%$ & $2.1 \%$ & $4.2 \%$ & $85.4 \%$ & $6.3 \%$ \\
\hline & & Post- & $0.0 \%$ & $0.0 \%$ & $0.0 \%$ & $20.0 \%$ & $80.0 \%$ \\
\hline
\end{tabular}

The psychological perspectives provide an outlook of how such factors as age, learner autonomy itself or the absence of it, focus on the learner teaching, motivation and self-evaluation could interact to one another, and then ultimately affect the the learners' success in learning. As shown Table 2 below, learners of all ages were perceivedby the majority of the teachers to have the capacity of developing autonomy (64.6\%), and therefore, it is equally feasible to develop learner autonomy in both young and adult learners. It is interesting that quite a few teachers, above $40 \%$ strongly disagreed or disagreed with the statement regarding the difficulty that learners could face when promoting learner autonomy among proficient language learners as compared to beginners. Learners with different language proficiency levels could develop their autonomy in learning, especially 
by implementing a learner-centered approach to teaching $(89.6 \%)$, which in turn could contribute to language learners' success in learning the target language (93.8\%). Being autonomous has somethingto do with the ability of the learners in assessing their own learning (87.5\%). The perception regarding the role of a teacher in promoting LA in these psychological perspectives is similar to that in the technical ones, viz. the majority of the teachers perceived positively the statement saying that learner autonomy cannot develop without the help of the teacher (70.9\%).

Table 2.Teachers' perceptions on LA: Psychological perspectives

\begin{tabular}{|c|c|c|c|c|c|c|c|}
\hline No & Selected Statements & 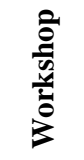 & 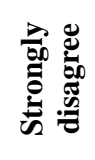 & 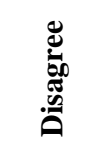 & 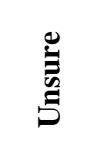 & $\frac{8}{\square}$ & 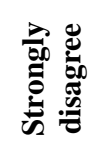 \\
\hline \multirow[t]{2}{*}{1.} & \multirow{2}{*}{ Language learners of all ages can develop LA. } & Pre- & $2.1 \%$ & $12.5 \%$ & $20.8 \%$ & $56.3 \%$ & $8.3 \%$ \\
\hline & & Post- & $0.0 \%$ & $23.3 \%$ & $30.0 \%$ & $6.7 \%$ & $40.0 \%$ \\
\hline \multirow[t]{2}{*}{2.} & \multirow{2}{*}{$\begin{array}{l}\text { It is harder to promote LA with proficient languagelearners } \\
\text { than it is with beginners. }\end{array}$} & Pre- & $8.3 \%$ & $33.3 \%$ & $37.5 \%$ & $16.7 \%$ & $4.2 \%$ \\
\hline & & Post- & $26.7 \%$ & $60.0 \%$ & $3.3 \%$ & $3.3 \%$ & $6.7 \%$ \\
\hline \multirow[t]{2}{*}{3.} & \multirow{2}{*}{ LA cannot develop without the help of the teacher. } & Pre- & $0.0 \%$ & $8.3 \%$ & $20.8 \%$ & $64.6 \%$ & $6.3 \%$ \\
\hline & & Post- & $0.0 \%$ & $10.0 \%$ & $10.0 \%$ & $6.7 \%$ & $73.3 \%$ \\
\hline \multirow[t]{2}{*}{4.} & \multirow{2}{*}{$\begin{array}{l}\text { Learner-centred classrooms provide ideal conditions for } \\
\text { developingLA. }\end{array}$} & Pre- & $4.2 \%$ & $2.1 \%$ & $4.2 \%$ & $\mathbf{7 5 . 0 \%}$ & $14.6 \%$ \\
\hline & & Post- & $0.0 \%$ & $0.0 \%$ & $3.3 \%$ & $56.7 \%$ & $40.0 \%$ \\
\hline \multirow[t]{2}{*}{5.} & \multirow{2}{*}{ LA has a positive effect on success as a language learner. } & Pre- & $2.1 \%$ & $2.1 \%$ & $2.1 \%$ & $56.3 \%$ & $\mathbf{3 7 . 5 \%}$ \\
\hline & & Post- & $0.0 \%$ & $0.0 \%$ & $0.0 \%$ & $46.7 \%$ & $53.3 \%$ \\
\hline \multirow[t]{2}{*}{6.} & \multirow{2}{*}{$\begin{array}{l}\text { To become autonomous, learners need to develop the } \\
\text { abilityto evaluate their own learning. }\end{array}$} & Pre- & $0.0 \%$ & $0.0 \%$ & $12.5 \%$ & $54.2 \%$ & $33.3 \%$ \\
\hline & & Post- & $0.0 \%$ & $0.0 \%$ & $3.3 \%$ & $40.0 \%$ & $56.7 \%$ \\
\hline
\end{tabular}

As mentioned earlier, the political perspectives include rights of the learners in the classroom, which are commonly unexpected to occur in the traditional, common classroom.A more detailed information regarding these particular perspectives is displayed in Table 3 below. Regular opportunities for task completion that should be carried out alone by the learner were thought of by most of the teachers (more than 60\%) to have the potential to promote learner autonomy. In the same way, almost all of the teachers were in agreement thatfreedom in choosing how the learners learn, selecting activities for the learners to work on, and involving them to decide what to learncould all promote learner autonomy. Quite a few teachers $(48.0 \%)$ would reject the traditional teacher-led ways of teaching, although they positively perceived $(93.8 \%)$ that the teacher's role was needed to enhance learner autonomy. Even in the area of learning assessment, more than half of the teachers $(52.1 \%)$ believed that they should involve the students in deciding how their learning would be assessed.

Table 3.Teachers' perceptions on LA: Political perspectives

\begin{tabular}{|c|c|c|c|c|c|c|c|}
\hline No & Statement & $\begin{array}{l}\frac{0}{0} \\
\frac{1}{5} \\
\frac{0}{2} \\
\dot{0}\end{array}$ & 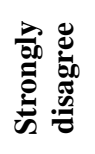 & 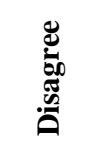 & 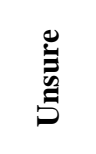 & 离 & 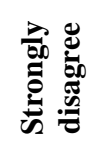 \\
\hline \multirow[t]{2}{*}{1.} & \multirow{2}{*}{$\begin{array}{l}\text { LA is promoted through regular opportunitiesfor learners to } \\
\text { complete tasks alone. }\end{array}$} & Pre- & $4.2 \%$ & $14.6 \%$ & $18.8 \%$ & $56.3 \%$ & $6.3 \%$ \\
\hline & & Post- & $0.0 \%$ & $13.3 \%$ & $13.3 \%$ & $16.7 \%$ & $56.7 \%$ \\
\hline \multirow[t]{2}{*}{2.} & \multirow{2}{*}{$\begin{array}{l}\text { Autonomy means that learners can make choices about } \\
\text { howthey learn. }\end{array}$} & Pre- & $2.1 \%$ & $2.1 \%$ & $2.1 \%$ & $66.7 \%$ & $27.1 \%$ \\
\hline & & Post- & $0.0 \%$ & $0.0 \%$ & $16.7 \%$ & $33.3 \%$ & $50.0 \%$ \\
\hline \multirow[t]{2}{*}{3.} & \multirow{2}{*}{$\begin{array}{l}\text { Involving learners in decisions about what to learn } \\
\text { promotesLA. }\end{array}$} & Pre- & $2.1 \%$ & $8.3 \%$ & $8.3 \%$ & $54.2 \%$ & $27.1 \%$ \\
\hline & & Pos & $0.0 \%$ & $0.0 \%$ & $6.7 \%$ & $43.3 \%$ & $50.0 \%$ \\
\hline \multirow[t]{2}{*}{4.} & \multirow{2}{*}{$\begin{array}{l}\text { LA is promoted when learners have some choicein the kinds } \\
\text { of activities they do. }\end{array}$} & Pre- & $2.1 \%$ & $0.0 \%$ & $12.5 \%$ & $77.1 \%$ & $8.3 \%$ \\
\hline & & Post- & $0.0 \%$ & $0.0 \%$ & $3.3 \%$ & $23.3 \%$ & $73.3 \%$ \\
\hline \multirow[t]{2}{*}{5.} & \multirow{2}{*}{ LA cannot be promoted in teacher-centred classrooms. } & Pre- & $4.2 \%$ & $18.8 \%$ & $27.1 \%$ & $35.4 \%$ & $14.6 \%$ \\
\hline & & Post- & $0.0 \%$ & $6.7 \%$ & $3.3 \%$ & $20.0 \%$ & $70.0 \%$ \\
\hline & \multirow{2}{*}{$\begin{array}{l}\text { LA implies a rejection of traditional teacher-ledways of } \\
\text { teaching. }\end{array}$} & Pre- & $0.0 \%$ & $14.6 \%$ & $37.5 \%$ & $41.7 \%$ & $6.3 \%$ \\
\hline & & Post- & $0.0 \%$ & $6.7 \%$ & $3.3 \%$ & $26.7 \%$ & $63.3 \%$ \\
\hline \multirow[t]{2}{*}{7.} & \multirow{2}{*}{$\begin{array}{l}\text { LA is promoted when learners are free to decidehow their } \\
\text { learning will be assessed. }\end{array}$} & Pre- & $2.1 \%$ & $10.4 \%$ & $35.4 \%$ & $50.0 \%$ & $2.1 \%$ \\
\hline & & Post- & $0.0 \%$ & $6.7 \%$ & $16.7 \%$ & $23.3 \%$ & $53.3 \%$ \\
\hline \multirow[t]{2}{*}{8.} & \multirow{2}{*}{$\begin{array}{l}\text { LA is promoted when learners can choose theirown learning } \\
\text { materials. }\end{array}$} & Pre- & $0.0 \%$ & $8.3 \%$ & $18.8 \%$ & $70.8 \%$ & $2.1 \%$ \\
\hline & & Post- & $0.0 \%$ & $0.0 \%$ & $3.3 \%$ & $30.0 \%$ & $66.7 \%$ \\
\hline \multirow[t]{2}{*}{9.} & \multirow[t]{2}{*}{ The teacher has an important role to play in supportingLA. } & Pre- & $0.0 \%$ & $0.0 \%$ & $6.3 \%$ & $66.7 \%$ & $27.1 \%$ \\
\hline & & Post- & $0.0 \%$ & $0.0 \%$ & $0.0 \%$ & $46.7 \%$ & $53.3 \%$ \\
\hline
\end{tabular}


As regards the socio-cultural perspectives, more than $80 \%$ of the teachers believed that perceptions on learner autonomy were not influenced by their different cultural backgrounds. A number of the teachers showed their strong disagreement or disagreement, when they were asked whether learner autonomy is not suited to non-Western leaners. The majority of the teachers shared the perception that learning from one another could promote LA. In addition, Table 4 below also shows that cooperative group work enhanced the development of LA.

Table 4.Teachers' perceptions on LA: Socio-cultural perspectives

\begin{tabular}{|c|c|c|c|c|c|c|c|}
\hline No & Statement & $\begin{array}{l}\frac{2}{a} \\
\frac{\pi}{n} \\
\frac{\pi}{a} \\
3\end{array}$ & 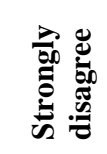 & 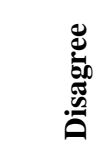 & 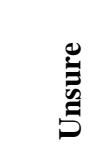 & 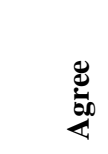 & 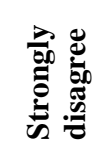 \\
\hline \multirow{2}{*}{\multicolumn{2}{|c|}{ 1. LA can be achieved by learners of all cultural backgrounds. }} & Pre- & $0.0 \%$ & $4.2 \%$ & $10.4 \%$ & $\mathbf{7 0 . 8 \%}$ & $14.6 \%$ \\
\hline & & Post- & $3.3 \%$ & $0.0 \%$ & $20.0 \%$ & $23.3 \%$ & $53.3 \%$ \\
\hline \multirow{2}{*}{\multicolumn{2}{|c|}{$\begin{array}{l}\text { 2. LA is promoted through activities which give learners } \\
\text { opportunities to learn from each other. }\end{array}$}} & Pre- & $2.1 \%$ & $2.1 \%$ & $4.2 \%$ & $68.8 \%$ & $22.9 \%$ \\
\hline & & Post- & $3.3 \%$ & $0.0 \%$ & $10.0 \%$ & $46.7 \%$ & $40.0 \%$ \\
\hline \multirow{2}{*}{\multicolumn{2}{|c|}{ 3. LA is a concept which is not suited to non-Western learners. }} & Pre- & $20.8 \%$ & $39.6 \%$ & $22.9 \%$ & $16.7 \%$ & $0.0 \%$ \\
\hline & & Post- & $16.7 \%$ & $66.7 \%$ & $16.7 \%$ & $0.0 \%$ & $0.0 \%$ \\
\hline \multirow{2}{*}{\multicolumn{2}{|c|}{$\begin{array}{l}\text { 4. Co-operative group work activities support the development } \\
\text { of LA. }\end{array}$}} & Pre- & $0.0 \%$ & $2.1 \%$ & $6.3 \%$ & $77.1 \%$ & $14.6 \%$ \\
\hline & & Post- & $0.0 \%$ & $3.3 \%$ & $0.0 \%$ & $33.3 \%$ & $63.3 \%$ \\
\hline
\end{tabular}

\section{LA-based teaching-learning practices}

Teaching-learning practices were indicated by the responses from the participating teachers as regards desirability and feasibility of the practices in their daily activities. The responses to indicators of involving learners in making decisions are shown in Table 5 below. Involving learners in making decision was found to be varied, depending upon types of activities. It was found that discussing the topic with the students was the most desirable and the most feasible teaching-learning practice in the classroom, whereas talking about how learning is assessed with the students was the most undesirable and the least feasible. As regards provision to the students the right to decide what objectives the course should be aimed at, the teachers were split, almost half and half,by considering that it wasvery desirable $(34.4 \%)$, but as to feasibility the same percentage went down to quite feasible, instead of very feasible, meaning that it could be good to let the learners involved in discussing the aims, but not that feasible probably considering the learners' capacity.

Table 5. Teaching-learning practices: Involving learners in making decisions

\begin{tabular}{|c|c|c|c|c|c|c|c|c|}
\hline \multirow{2}{*}{ Decision about } & \multicolumn{4}{|c|}{ Desirability } & \multicolumn{4}{|c|}{ Feasibility } \\
\hline & 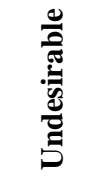 & 窇泀 & 㟒泀 & 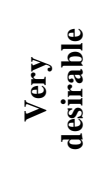 & 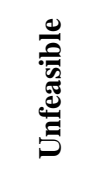 & 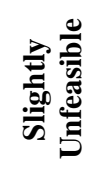 & 总 总 & 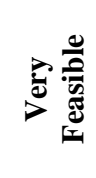 \\
\hline The objectives of a course & $15.6 \%$ & $3.1 \%$ & $18.8 \%$ & $34.4 \%$ & $21.9 \%$ & $25.0 \%$ & $34.4 \%$ & $18.8 \%$ \\
\hline The materials used & $6.3 \%$ & $12.5 \%$ & $46.9 \%$ & $34.4 \%$ & $12.5 \%$ & $25.0 \%$ & $43.8 \%$ & $18 . \%$ \\
\hline The kinds of tasks and activities they do & $9.4 \%$ & $28.1 \%$ & $34.4 \%$ & $28.1 \%$ & $9.4 \%$ & $21.9 \%$ & $59.4 \%$ & $9.4 \%$ \\
\hline The topics discussed & $3.1 \%$ & $9.4 \%$ & $46.9 \%$ & $40.6 \%$ & $9.4 \%$ & $12.5 \%$ & $53.1 \%$ & $25.0 \%$ \\
\hline How learning is assessed & $18.8 \%$ & $21.9 \%$ & $46.9 \%$ & $12.5 \%$ & $31.3 \%$ & $21.9 \%$ & $40.6 \%$ & $6.3 \%$ \\
\hline The teaching methods used & $12.5 \%$ & $12.5 \%$ & $53.1 \%$ & $21.9 \%$ & $15.6 \%$ & $43.8 \%$ & $37.5 \%$ & $3.1 \%$ \\
\hline Classroom management & $6.3 \%$ & $12.5 \%$ & $46.9 \%$ & $34.4 \%$ & $12.5 \%$ & $15.6 \%$ & $56.3 \%$ & $15.6 \%$ \\
\hline
\end{tabular}

Table 5 also shows that getting learners involved in making decisions about the materials used is slightly differently perceived by the teachers compared to providing opportunities as mentioned above to the learners to determine the objectives of the course. The majority of the teachers perceived that involving learners to decide about the materials used was desirable, and at the same time they also believed that it was also considered by quite a few teachers as a feasible LA-based activity to take place in the classroom. Involving learners to make decisions in choosing the materials was considered by only a very small number of teachers as undesirable and unfeasible. A somewhat similar belief was indicated by the teachers as regards learners' involvement in selecting the kinds of tasks and activities they do. This classroom practice was considered by the majority of the teachers as both desirable and feasible.

Table 5 above also shows how the teachers responded to four other classroom practices: topics, assessment, teaching methods, and classroom 
management. The majority of the teachers believed that learners should be given freedom to discuss the topics as this classroom practice was both desirable and feasible to take place. However, assessment seemed to be perceived by most of the teachers as their prerogative. Discussing it with the students was considered both undesirable, but slightly feasible.

Teaching methods were differently perceived by the teachers, different from assessment. The majority of the teachers considered involving learners to make decisions about the teaching methods desirable, but somewhat unfeasible. This could be interpreted that it was possible for learners to negotiate about what the teaching methods to use, but the teachers were not sure if this could be made into reality as the knowledgeability of the learners regarding existing methods was not sufficient for them to select which one was appropriate. As regards classroom management, the majority believed that classroom management could be discussed with the students, and it was considered as a feasible activity.

\section{LA training for professional development}

A training inthe form of a series of workshops was carried out to all teachers participating in this study. The training outlined the definition of learner autonomy and discussed the principles of LA. During the training, the participants were also provided with different tasks and activities in line with LA. The participants were to complete the questionnaire before and after the LA training to see whether their perceptions regarding LA positively changed.

Out of the seven items in the questionnaire, regarding the technical perspectives as can be seen in Table 6 below, three statements were significantly differently perceived before and after the LA training. The statements regarding independent study in the library, learning independent work in a self access center, and use of the internet to promote learner autonomy were significantly different with 2-tailed significances of .004, .013, and .000 respectively. Thus, the efforts of providing professional development workshops have a positive contribution to improvement in the beliefs of the teachers regarding learner autonomy. Table 6 provides an overall picture of how the items regarding learner autonomy technical perspectives were differently responded before and after the professional development focus group discussion.

Table 6. Paired Sample t-test (Pre-training and Post-training):Technical perspectives of the teachers' perceptions in LA

\begin{tabular}{|c|c|c|c|c|c|c|}
\hline No & Statement & 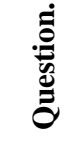 & Mean & $\mathbf{T}$ & Df & $\begin{array}{c}\text { Sig. } \\
(2- \\
\text { tailed) }\end{array}$ \\
\hline & Independent study in the library is an activity which developsLA. & $\begin{array}{l}\text { Pre- } \\
\text { Post- }\end{array}$ & $\begin{array}{l}3.9333 \\
4.5000\end{array}$ & 3.084 & 29 & .004 \\
\hline & LA is promoted by independent work in a self-access centre. & $\begin{array}{l}\text { Pre- } \\
\text { Post- }\end{array}$ & $\begin{array}{l}3.7667 \\
4.3000 \\
\end{array}$ & 2.641 & 29 & .013 \\
\hline & $\begin{array}{l}\text { Out-of-class tasks which requires learners to use the internet promote } \\
\text { LA. }\end{array}$ & $\begin{array}{l}\text { Pre- } \\
\text { Post- }\end{array}$ & $\begin{array}{l}4.0333 \\
4.8000 \\
\end{array}$ & 7.389 & 29 & .000 \\
\hline
\end{tabular}

As regards the psychological perspectives, a similar view was also found, that is, the teachers' beliefs improved significantly after the professional development workshops were carried out, particularly on the issues of proficient versus beginner learners (sig.at .008), confident learners and those with no confidence (sig. at.026), effective learning(sig. at .003), teacher help (sig. at .000), learner-centeredness (sig. at.039), workalone learning (sig. at 003), and ability to monitor one's own learning (sig. at.002). Table 7 shows a more detailed results of the paired sample t-test regarding the psychological perspectives. These data indicate that the beliefs of the teachers as regards levels of language proficiency in promoting learner autonomy improved significantly after the workshops, so did their belief about equal possibility in promoting learner autonomy across ages, the role of the teacher in helping learners to develop autonomy, and about the significance of learners' working alone and being able to monitor their own learning.

The beliefs of the teachers in the study improved significantly in almost all politicalperspective items in the questionnaire after the professional development workshops were conducted. It has been found in the results of paired sample t-test that provisions of regular opportunities to complete tasks alone (sig. at .000), free choice of the kinds of activities the learners do (sig. at .000), non-teacher-centered classrooms (sig. at .000), freedom to decide how to assess how and how much to learn (sig. at .001) and what to learn (.000) were believed with a better standpoint after the workshops to have the the potential of promoting leaner autonomy. This set of beliefs among the teachers in the study indicate positive views regarding what to provide and what materials and 
activities to offer in order to better promote the learners' learning activity. These data could be more comprehensively seen in Table 8 .

Table 7. Paired Sample t-test (Pre-training and Post-training):Psychological perspectives of the teachers' beliefs in LA

\begin{tabular}{|c|c|c|c|c|c|c|}
\hline No & Statement & 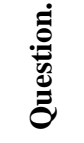 & Mean & $\mathbf{T}$ & df & $\begin{array}{c}\text { Sig. } \\
(2- \\
\text { tailed) }\end{array}$ \\
\hline \multirow[t]{2}{*}{1.} & \multirow{2}{*}{$\begin{array}{l}\text { It is harder to promote LA with proficient languagelearners than it is } \\
\text { with beginners. }\end{array}$} & Pre- & 2.7333 & \multirow{2}{*}{$\begin{array}{r}- \\
2.855 \\
\end{array}$} & \multirow[t]{2}{*}{29} & \multirow{2}{*}{.008} \\
\hline & & $\frac{\text { Post- }}{\text { Pre }}$ & $\frac{2.0333}{3.6333}$ & & & \\
\hline & $\begin{array}{l}\text { It is possible to promote LA with both younglanguage learners and } \\
\text { with adults. }\end{array}$ & $\begin{array}{l}\text { Pre- } \\
\text { Post- }\end{array}$ & $\begin{array}{l}3.6333 \\
4.1667\end{array}$ & 2.040 & 29 & .051 \\
\hline & \multirow{2}{*}{$\begin{array}{l}\text { Confident language learners are more likely to develop autonomythan } \\
\text { those who lack confidence. }\end{array}$} & Pre- & 3.8333 & \multirow{2}{*}{2.347} & \multirow{2}{*}{29} & \multirow{2}{*}{.026} \\
\hline & & Post- & 4.3333 & & & \\
\hline & \multirow{2}{*}{$\begin{array}{l}\text { LA allows language learners to learn more effectively than they } \\
\text { otherwise would. }\end{array}$} & Pre- & 3.9000 & \multirow{2}{*}{3.195} & \multirow{2}{*}{29} & \multirow{2}{*}{.003} \\
\hline & & Post- & 4.4667 & & & \\
\hline & \multirow[t]{2}{*}{ LA cannot develop without the help of the teacher. } & Pre- & 3.6667 & \multirow{2}{*}{4.038} & \multirow{2}{*}{29} & \multirow{2}{*}{.000} \\
\hline & & Post- & 4.4333 & & & \\
\hline & \multirow{2}{*}{$\begin{array}{l}\text { Promoting autonomy is easier with beginning language learnersthan } \\
\text { with more proficient learners. }\end{array}$} & Pre- & 2.9000 & \multirow{2}{*}{2.632} & \multirow{2}{*}{29} & \multirow{2}{*}{.013} \\
\hline & & Post- & 2.3000 & & & \\
\hline \multirow{2}{*}{\multicolumn{2}{|c|}{$\begin{array}{l}\text { 7. Learner-centred classrooms provide ideal conditions for } \\
\text { developingLA. }\end{array}$}} & Pre- & 4.0333 & \multirow{2}{*}{2.163} & \multirow{2}{*}{29} & \multirow{2}{*}{.039} \\
\hline & & Post- & 4.3667 & & & \\
\hline \multirow{2}{*}{\multicolumn{2}{|c|}{ 8. Learning to work alone is central to the development ofLA. }} & Pre- & 3.2000 & \multirow{2}{*}{3.247} & \multirow{2}{*}{29} & 003 \\
\hline & & Post- & 4.0000 & & & .000 \\
\hline & The ability to monitor one's learning is central to LA. & Pre- & 3.9000 & 3.319 & 29 & .002 \\
\hline & & Post- & 4.4667 & & & \\
\hline
\end{tabular}

Table 8. Paired Sample t-test (Pre-training and Post-training):Political perspectives of the teachers' perceptions in LA

\begin{tabular}{|c|c|c|c|c|c|}
\hline Statement & 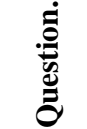 & Mean & $\mathbf{t}$ & df & $\begin{array}{c}\text { Sig. } \\
(2- \\
\text { tailed) }\end{array}$ \\
\hline \multirow{2}{*}{$\begin{array}{l}\text { 1. LA is promoted through regular opportunitiesfor learners to complete } \\
\text { tasks alone. }\end{array}$} & Pre- & 3.3000 & \multirow{2}{*}{4.176} & \multirow[b]{2}{*}{29} & \multirow{2}{*}{.000} \\
\hline & Post- & 4.1667 & & & \\
\hline \multirow{2}{*}{$\begin{array}{l}\text { LA is promoted when learners have some choicein the kinds of } \\
\text { activities they do. }\end{array}$} & Pre- & 4.0333 & \multirow{2}{*}{3.959} & \multirow{2}{*}{29} & \multirow{2}{*}{.000} \\
\hline & Post- & 4.7000 & & & \\
\hline \multirow[t]{2}{*}{ 3. LA cannot be promoted in teacher-centred classrooms. } & Pre- & 3.4667 & \multirow{2}{*}{6.186} & \multirow{2}{*}{29} & \multirow{2}{*}{.000} \\
\hline & Post- & 4.5333 & & & \\
\hline \multirow[t]{2}{*}{ 4. LA implies a rejection of traditional teacher-ledways of teaching. } & Pre- & 3.5333 & \multirow{2}{*}{5.037} & \multirow{2}{*}{29} & \multirow{2}{*}{.000} \\
\hline & Post- & 4.4667 & & & \\
\hline \multirow[t]{2}{*}{ decidehow their lear } & Pre- & 3.4333 & \multirow{2}{*}{3.607} & \multirow{2}{*}{29} & \multirow{2}{*}{.001} \\
\hline & Post- & 4.2333 & & & \\
\hline \multirow[t]{2}{*}{ promoted } & Pre- & 3.5333 & \multirow{2}{*}{6.528} & \multirow{2}{*}{29} & \multirow{2}{*}{.000} \\
\hline & Post- & 4.6333 & & & \\
\hline
\end{tabular}

As indicated in a previous section of this report that the teachers have indicated very strong agreement with all the items belonging to the sociocultural perspectives with the mean scores close to and above 4.0 on a five scale basis, as indicated in Table 9 below, whereas the pre-workshop score of 2.1667 and the post-workshop score of 2.000 are assigned to the negative item saying that learner autonomy is a concept which is not suited to nonWestern learners. This means that the teachers would tend to disagree with such a partial outlook differentiating Western and non-Western learners. As to the impact given by the professional development workshops, the significant difference was found between pre- and post-workshop beliefs of the teachers, as regards the importance of encouraging learners to work together (sig. at.000) and creating group work activities to support the development of learner autonomy (sig. at .003). 
Table 9. Paired Sample t-test (Pre-training and Post-training):Socio-cultural perspectives of the teachers' perceptions in LA

\begin{tabular}{|c|c|c|c|c|c|c|}
\hline No & Statement & 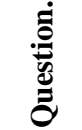 & Mean & $\mathbf{t}$ & df & $\begin{array}{c}\text { Sig. } \\
(2- \\
\text { tailed) }\end{array}$ \\
\hline \multirow{2}{*}{\multicolumn{2}{|c|}{ 1. LA can be achieved by learners of allcultural backgrounds. }} & Pre- & 3.9333 & \multirow{2}{*}{1.964} & \multirow{2}{*}{29} & \multirow{2}{*}{.059} \\
\hline & & Post- & 4.2333 & & & \\
\hline \multirow{2}{*}{\multicolumn{2}{|c|}{ LA is promoted by activities that encourage learnersto work together. }} & Pre- & 3.8333 & \multirow{2}{*}{4.942} & \multirow{2}{*}{29} & \multirow{2}{*}{.000} \\
\hline & & Post- & 4.6333 & & & \\
\hline \multirow[t]{2}{*}{3.} & Co-operative group work activities support the developmentof LA. & Pre- & 4.1000 & \multirow{2}{*}{3.294} & \multirow{2}{*}{29} & \multirow{2}{*}{.003} \\
\hline & & Post & 4.5667 & & & \\
\hline
\end{tabular}

\section{CONCLUSION}

Considering the problems of Indonesian students rank lowest among those from ASEAN countries as regards their abilitybeyond the solution of routine problems, which seems reachable only for relatively autonomous learners, a change is needed in the teaching-learning process paradigms from just transferring knowledge by the teacher to the learners finding needed information by themselves. Autonomy was not yet common among Indonesian students, but studies as reported earlier have indicated that in the Indonesian contexts learner autonomy is a necessity and has a significant impact on EFL learning. In this study, interesting findings have been put forward, as regards teachers' perceptions on LA, their LA-based teachinglearning practices, and how LA training could contribute to LA perceptions. Some of the findings in this study are as follows.

It was revealed that the teachers in the present study tended to maintainthat autonomy should be inculcated among learners, and that the concept of learner autonomy should not be misinterpreted as learningwithout a teacher. Concerning choices and decisions by the learners, it was believed by the majority of the teachers that learners' making choices about how they learned and what activities they did, and involving them to decide what and how to learn could promote autonomy among learners.

As regards LA-based teaching-learning practice, it was revealed by the majority of the teachers that they desired to implement LA principles in their teaching-learning contexts, although they identified that many of the LA principles were not that feasible to apply in their situation. This finding is similar to what has been reported by Borg and Al-Busaidi (2012). Regarding the feasibility of teacher-learner negotiation as to how to conduct the teaching-learning process, the Indonesian teachers tended to be uncertain whether this could be put into practice, due probably to the beliefs among the teachers that their students did not have sufficient knowledge about teaching methodology.
It was also found that LA training could improve the teachers' perceptions regarding LA concepts and principles. There were some constraints as reported by the teachers during the LA training that made learner autonomy difficult to develop among Indonesian learners in general. Some of the identified constraints were limited time allotedfor the implementation of the the curriculum, learners' lack of autonomous learning experience, too much focus on national examinations, and insufficient proficiency of English among the learners. In dealing with the constraints, the teachers indicated that with professional commitment to plan and make pedagogical tasks work in the classroom, they could make use of available access to various different resources, such as books and other printed materials in the school library and materials available in the internet. Commitment is certainly the key to success in teaching, besides competence in the field study to be taught and coordination with other teachers of the same subjects. Commitment of teachers to their profession is a significant variable to make teachinglearning efforts fruitful. This should become a prioritized area of concern for near future research.

\section{REFERENCES}

Baswedan, A.(2014). Ministerial presentation at the Ministry of Education and Culture for the Head of Provincial and Municipal Educational Authorities (Kadisdik).

Benson, P.,\& Huang, J. (2008). Autonomy in the transition from foreign language learning to foreign language teaching. DELTA vol. 24. Retrieved January 17, 2015 from http://www.scielo.br/scielo.php?pid=S0102445 02008000300003script=sci_arttext\&tl Ministerial presentation at $\mathrm{ng}=\mathrm{pt}$

Benson, P. (2007). Autonomy in language teaching and learning. Language Teaching, 40, 21-40. doi:10.1017/S0261444806003958.

Benson, P., Chik, A.,\& Lim, H. Y. (2003). Becoming autonomous in an Asian context: Autonomy as a sociocultural process.In David Palfreyman and Richard C. Smith (eds.). 
Learner autonomy across cultures: Language education perspectives. New York, N.Y.: Palgrave pp. 23-40.

Borg, S. \& Al-Busaidi, S. (2012). Learner autonomy: English language teachers' beliefs and practices. London, England: British Council \& University of Leeds.

Cohen,A.D.\&Macaro, E. (2013). Language learner strategies. Oxford: Oxford University Press.

Cotterall, S. (2008). Autonomy and good language learners.In C. Griffith (Ed.). Lessons from good language learners (pp.110-120). Cambridge, England: Cambridge University Press.

Dornyei, Z. (2011). Motivational strategies in the language classroom. Cambridge: Cambridge University Press.

Hamied, F.A. (2011). English as a Lingua Franca: An Indonesian perspective. A plenary presentation at the Fourth International Conference of English as a Lingua Franca, Hong Kong.

Harmer, J. (2007). The practice of English language teaching. Kuala Lumpur: Pearson Education Limited

Kemala, Z. (2014). An analysis of autonomous learning strategies used by senior high school students (Unpublished master thesis). Universitas Pendidikan Indonesia Bandung, Indonesia.

Kumaravadivelu, B. 2003. Beyond methods: Macrostrategies for language teaching. New Haven and London: Yale University Press.

Lamb, M. (2004). It depends on the students themselves': Independent language learning in an Indonesian state schools. Language, Culture, and Curriculum.17(3), 229-245

Lengkanawati, N.S. (1997). Kontribusi strategi belajar Bahasa Inggris sebagai bahasa asing dan Bahasa Indonesia sebagai bahasa asing. (Unpublished doctoral dissertation). IKIP Bandung, Bandung, Indonesia.

Lengkanawati, N.S. (2014a). Making EFL learners autonomous: Can language learning strategies help? A paper presented at 2014 ALAK
International Conference "Applied Linguistics in the Era of Multiculturalism“, South Korea, September 27, 2014.

Lengkanawati, N.S. (2014b). Learning achievement as reflected in language learning strategies and learner autonomy. A paper presented at TEFLIN International Conference, 6-9 October, 2014.

Ministry of Education.(2012). 2013 curriculum development. A presentation at Indonesia University of Education Campus, December 2012, Bandung Indonesia.

Miyartawan, I. P. N. W. (2013). The correlation between LA and English proficiency of EFL college learners. TEFLIN Journal, 24(1) ,6281.

Mullis, I. V. S., Martin, M. O., Foy, P., \& Arora, A. (2012). TIMSS 2011 international results in mathematics. Chestnut Hill, MA: IEA, TIMSS \& PIRLS International Study Center, Lynch School of Education, Boston College.

Nuh, M. (2013). Pengembangan Kurikulum 2013. Ministerial presentation at Universitas Pendidikan Indonesia, Bandung, Indonesia, 16 March 2013.

Oxford, R. L. (1990). Language learning strategies: What every teacher should know. Boston, Massachusetts: Heinle \& Heinle Publisher.

Oxford, R. L. (2003). Toward a more systematic model of L2 LA. In D. Palfreyman \& R.C.D. Smith (Eds.), Learner autonomy across culture (pp.75-91). Basingstoke: Palgrave Macmillan.

Suharmanto (2003). Learning autonomy: A way to improve English languageteaching (ELT) in Indonesia. TEFLIN Journal, 14(1), 111-122.

TIMSS Report.(2007). Accessed on 17 February, 2015 at $h t t p: / / n c e s . e d . g o v / t i m s s / t a b l e 07 \_1 . a s p$

Utami, R. (2007). The effects of autonomous learners to improve their English (Unpublished master thesis). Universitas Pendidikan Indonesia, Bandung, Indonesia.

Wenden, A. (1991). Strategies for learner autonomy. London: Prentice Hall International Ltd. 